\title{
EXPERIMENTAL RESEARCHES IN THE WAVE BASIN USING NATIONAL INSTRUMENTS TECHNOLOGY
}

\author{
Stanislav Sholar, Olga Ivanova, Veronika Dushko, Vadim Kramar \& Anna Rodkina
}
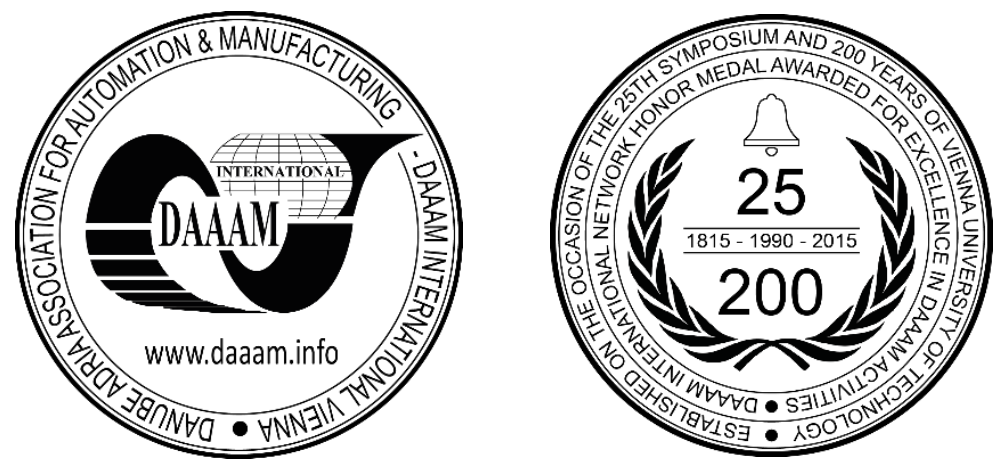

This Publication has to be referred as: Sholar, S[tanislav]; Ivanova, O[lga]; Dushko, V[eronika]; Kramar, V[adim] \& Rodkina, A[nna] (2016). Experimental Researches in the Wave Basin Using National Instruments Technology, Proceedings of the 27th DAAAM International Symposium, pp.0417-0422, B. Katalinic (Ed.), Published by DAAAM International, ISBN 978-3-902734-08-2, ISSN 1726-9679, Vienna, Austria

DOI: $10.2507 / 27$ th.daaam.proceedings.061

\begin{abstract}
The article is devoted to the possibility of using National Instrument analog-to-digital converter NI USB 6008 in experimental researches in the Sevastopol State University wave basin. The analog-to-digital converter using in experimental researches in experimental basin allows you to record all relevant data, such as the profile of the wave, the force of wave's impact, wave characteristics and their interaction with the test physical models of offshore constructions.
\end{abstract}

Keywords: wind and wave loads; offshore constructions; wave basin; analog-to-digital converter (ADC); Sevastopol State University (SevSU); National Instruments (NI) technology.

\section{Introduction}

At present, the world economy is on the threshold of industrial development of the continental shelf (about $22 \%$ of the world ocean shelf).

Oil and gas offshore exploitation is released as a priority activity that contribute to the development of the oil and gas industry and the economy as a whole. Shelf exploitation will require the development of a whole range of new technological solutions for the exploitation of hydrocarbons in extreme conditions. In particular, it requires the development and implementation of specialized underwater equipment for the successful development of offshore fields, are characterized by complex and severe ice conditions (in the Arctic); development of exploitation of a wide range of modern technical means for the development of offshore oil and gas resources, including the offshore rigs of various types (offshore ice-resistant drilling rig, semi-submersible drilling rig, offshore ice-resistant drilling rig, drilling vessels, etc.), gas carrier vessels, mining technology platforms (ice-resistant stationary, ship type, SPAR, TLP, etc.).

For example, in the Russian Federation under the program "Development of shipbuilding and equipment for the development of offshore fields in 2015 - 2030 years" is planned by 2030 to increase oil exploitation on the shelf is 5 times - from the current 13 million to 66.2 million tons; gas exploitation is planned to increase by 4 times - from 57 billion to 230 billion $\mathrm{m}^{3}$. The solution to these massive problems associated with the conduct of research, which include the present work aimed primarily at improving the reliability of these facilities offshore and reducing the risk of manmade disasters, which, unfortunately, occur at this time. 
In the investigation of wind and wave loads impact on the ocean engineering systems constructions, as well as in the investigation of the accidents causes, such as corrosion-mechanical and fatigue destruction, the dynamics of soil scouring under template fixed offshore platform or other types of platforms, are used both theoretical and experimental studying methods [1], [2], [3].

In general, theoretical methods in the form of mathematical models allow to describe and explain the relations of the explored system or object elements in a relatively wide range of the variable values. However, the construction of theoretical models inevitably introducing any limitations, assumptions, hypotheses, etc. Therefore, the problem of evaluating the reliability of the resulting model to the real process is arises. To do this, we conducted experimental verification of developed theoretical models. In most cases, the experimental research results provide an impetus to the theoretical generalization of the explored phenomenon. Research works in wave (experimental) basins are held in many areas of applied hydrodynamics, shipbuilding, marine technologies.

Scientists research works in the field of sea drilling platforms creation and use cover the period from 50th years of last century. The works devoted to questions of constructional design, stability and strength of such constructions are executed by A.A. Aliseychik, etc. [4], T. Douson [5], V.R. Dushko [6], A.V. Lukoshkov [7], A.P. Pronkin and S.S. Hvorostovskij [8], V.P. Shostak [9], V.G. Franchuk, etc. [10], [11]. Hydrodynamics researches of such installations can be found in M.F. Barshtejn works, etc. [12], V.R. Dushko, etc. [6], V.M. Kushnir, etc. [13], I.Sh. Halfin [14], N. Srinivasan [15], Z. Demirbilek [16] and other authors. Some questions of installation deduction forces calculations on a soil are considered and systematized by T. Douson [5], as well as in papers [17].

Research works in wave (experimental) basins are held in many areas of applied hydrodynamics, shipbuilding, marine technology. theoretical and experimental research in the directions: nonlinear dynamics ocean engineering systems; dynamic positioning of vessels; the protection of vessels and structures from corrosion and mechanical damage; the spatial distribution of the velocity of the wave and the steady flow over objects ocean technology; influence of soil movement (bottom sediment and dumping) on the stability of subsea pipelines are carried out at the Ocean Technology Research Laboratory of SevSU Graduate Chair of Ocean Technology and Shipbuilding.

The scheme of experimental research in the SevSU Ocean Technology Research Laboratory wave basin is shown in Figure 1. The main parameters of the basin: length $L_{b}=10 \mathrm{~m}$, breadth $B_{b}=3 \mathrm{~m}$, basin wall height $1.5 \mathrm{~m}$, depth (liquid level in the basin) $h_{b}=1.3 \mathrm{~m}$. Waves on the water surface are driven by pneumatically wave generator 7 , which consists of an air compressor and a rotary plug pipe socket. The plug rotation period is specified in the range of $T=0.5 \ldots 2 \mathrm{~s}$. Pipe socket output directed to the water surface, the pressure oscillation amplitude at the output is constant. Wash area which propagate along a basin as free waves is generated as a result of the variable pressure on the water surface. Sloping bottom which deviation angle from the horizontal plane is set in the range of from 5 to $20^{\circ}$ is arranged at the opposite end of the basin inclined bottom.

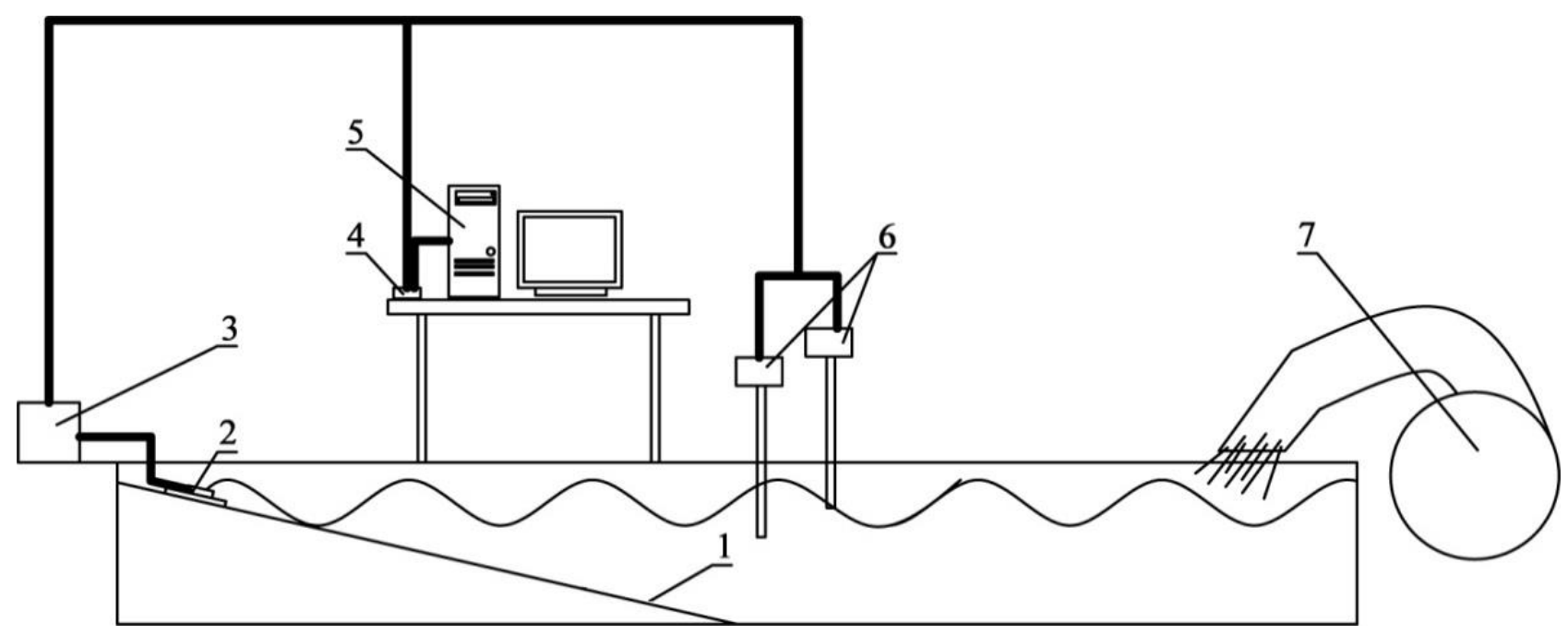

Fig. 1. The ocean technology laboratory test installation design. 1 - the sloping bottom; 2 - the aneroid box;

3 - the active filter box; 4 - the analog-to-digital converter (ADC) NI USB-6008

5 - the personal computer with the installed program LabView 8.5; 6 - the wave-recording gauges; 7 - the wave generator

For the purpose of experimental researches automation in the experimental basin, a complex of digital equipment has been created [18], [19], [20], allow for the measurement of the shock wave loads on the sloping bottom. To convert the electrical signals from the sensors to digital, complex chipset managed software product matter developed for each sensor separately is used [21]. 
For equipment switching, for converting analog signals to digital and then writing the data to the computer used ADC NI USB-6008 developed by National Instrument. Graphical programming language LabVIEW (Laboratory Virtual Instrumentation Engineering Workbench) are designed by NI to work with its devices. This language significantly changed and simplified a variety issues solving process, it allowed to solve issues without resorting to the professional programmers help in many cases. LabVIEW is a powerful graphical programming, a flexible software environment and user-friendly interface that is used for measurement and analysis.

\section{Special aspects of national instruments}

Using of National Instruments technology greatly simplifies the measurement process. The advantages of working with ADC NI USB-6008:

- increases accuracy;

- simplifies the implementation of different measurement methods in the certain experiment;

- time reduces the measuring channel settings;

- allows to organize experimental data processing algorithms.

Some experimental measurements can be carried out by the Internet remote access mode (for example, if you install the equipment on the beach).

Among the benefits of National Instruments technology highlighted next factors: the visibility of the code, easy to program and easy to use functional interface, and ease of matching hardware and software of the unified informationmeasuring system.

Technical aspects of NI USB 6008/6009:

- eight analog input channels, the definition of 12 or 14 bit, digitization rate up to $48 \mathrm{kHz}$;

- screw terminals for connecting the sensors;

- quick connection to the computer;

- drivers for operating systems Windows, Mac OS X and Linux;

- multifunction input/output for the collection and preservation of data;

- USB bus powering;

- free software to collect and store data.

\section{The application of NI technology in the ocean technology laboratory}

National Instrument equipment is successfully used in the SevSU experimental basin during the experimental research of wave impacts and shock loads on the physical models of ocean engineering structures. Analog-to-digital converter ADC NI USB 6008 is used to record values of the pneumatic type wave-recording gauge [22] on the basis of differential sensors firm "Motorola" MPX2010DP pressure type with a dynamic range and sensitivity of $10 \mathrm{kPa} 2.5 \mathrm{mV} / \mathrm{kPa}$ [23]. The first inputs of the sensors are attached to the rigid measuring tube length of $1 \mathrm{~m}$ and a diameter of $1 \mathrm{~cm}$, the ends of which are lowered to the desired depth $\mathrm{z}$, where they are exposed to the aqueous medium pressure. The second inputs of sensor output to open air, which provides compensation for atmospheric pressure changes in the output. The main features of the wave recorder include the ability to obtain data on the "inside" the structure of the wave positioning receiving ends of the tubes at different depths, and the relative simplicity and reliability, combined with high sensitivity and stability characteristics. The frequency of synchronous measurements of parameters of waves is equal to $50 \mathrm{~Hz}$, which is the range of possible wave disturbances periods $(0.5 \ldots 2)$ provides at least 25 samples per period of oscillation.

For treatment of common sets of measured data on selected rows of 10000 samples, the correlation functions of length was 250 samples, provided that the spectral window in the frequency range from 0.1 to $25 \mathrm{~Hz}$. The number of waves received is equal to compute spectra from 100 to 400, respectively, for the most low-frequency and high-frequency disturbances.

Representative examples of wave disturbance spectra are shown in Figure 2. The number of freedom degrees is equal to their estimates 80 that the distribution of Pearson $\left(\chi^{2}\right)$ to sample the spectrum estimates corresponding to a $95 \%$ probability inequality $0,87 \leq\left(S_{D} / S\right) \leq 1,13$, where $S_{D}$ - the actual value, $S$ - the selective evaluation of the spectrum. In Figure 2, the range of the specified sampling variability spectra shown straight line segments estimates.

As already noted, in the experiments using two identical wave recorder installed along the direction of wave propagation at a fixed distance. The phase shift between the readings of these sensors is used to determine the apparent wavelength and parameters of direct and reflected waves [24].

Figure 3 shows the change in amplitude of the wave measured in real time. Figure 3a shows two wave recorder connected to the laptop via the NI USB-6008. The first wave recorder (Figure $3 \mathrm{~b}-$ lower curve) at a depth of $5 \mathrm{~cm}$, the second (Figure $3 \mathrm{~b}$ - the upper curve). At a depth of $10 \mathrm{~cm}$, the distance between the wave recorder wave recorder installed $20 \mathrm{~cm}$ along the direction of wave propagation at a fixed distance. The phase shift between the readings wave recorder allows mathematically determine the characteristics of waves, such as wavelength $\lambda=0.8$ m, amplitude $a_{w}=0.03 \mathrm{~m}$, the wave period $\mathrm{T}=0,7 \mathrm{c}$. 


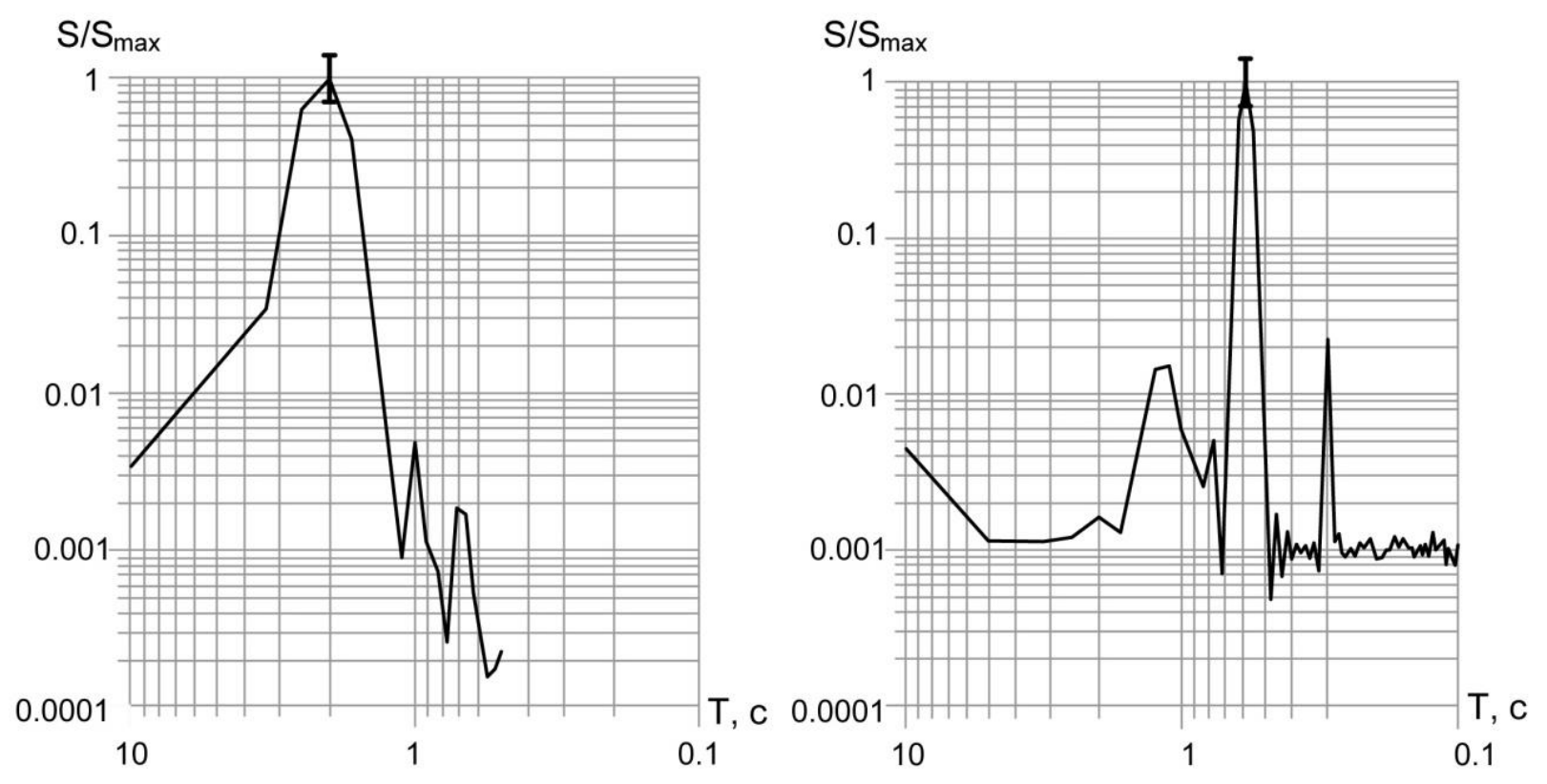

Fig. 2. Characteristic normalized spectra of wave disturbances in the experimental tank: left at the wave generator frequency of $0.5 \mathrm{~Hz}$, right $-1.7 \mathrm{~Hz}$.

The vertical lines show the range of sampling variability of estimates with $95 \%$ probability

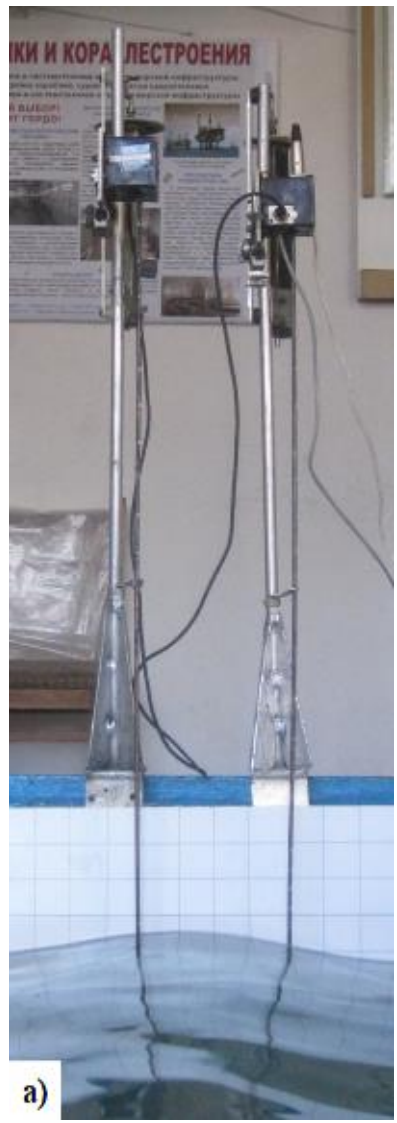

b)

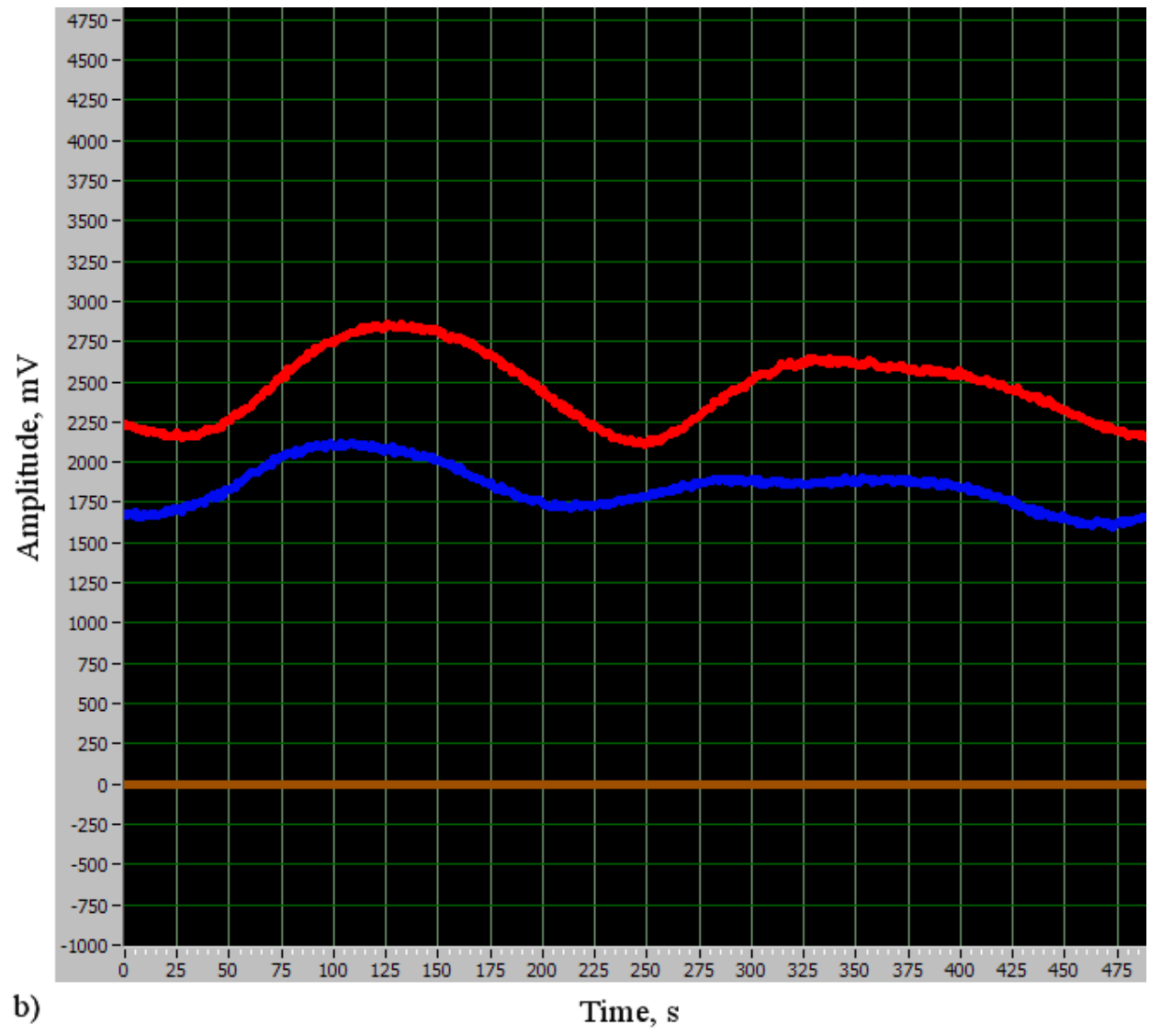

Fig. 3. Wave amplitudes recording in real time:

$a-2$ two wave-recording gauges mounted on the wave basin wall; $b$ - screenshot

Figure 4 shows the organization of data records in a text file; recording frequency and the number of points can be adjusted. The signal obtained by ADC can be software strengthened just before recording. As a rule, frequency of $50 \mathrm{~Hz}$. Recording duration is unlimited, but for the statistical programs of laboratory experiments data computing in experimental basins is most applicable to the recording duration of $200 \mathrm{~s}$ [21]. 


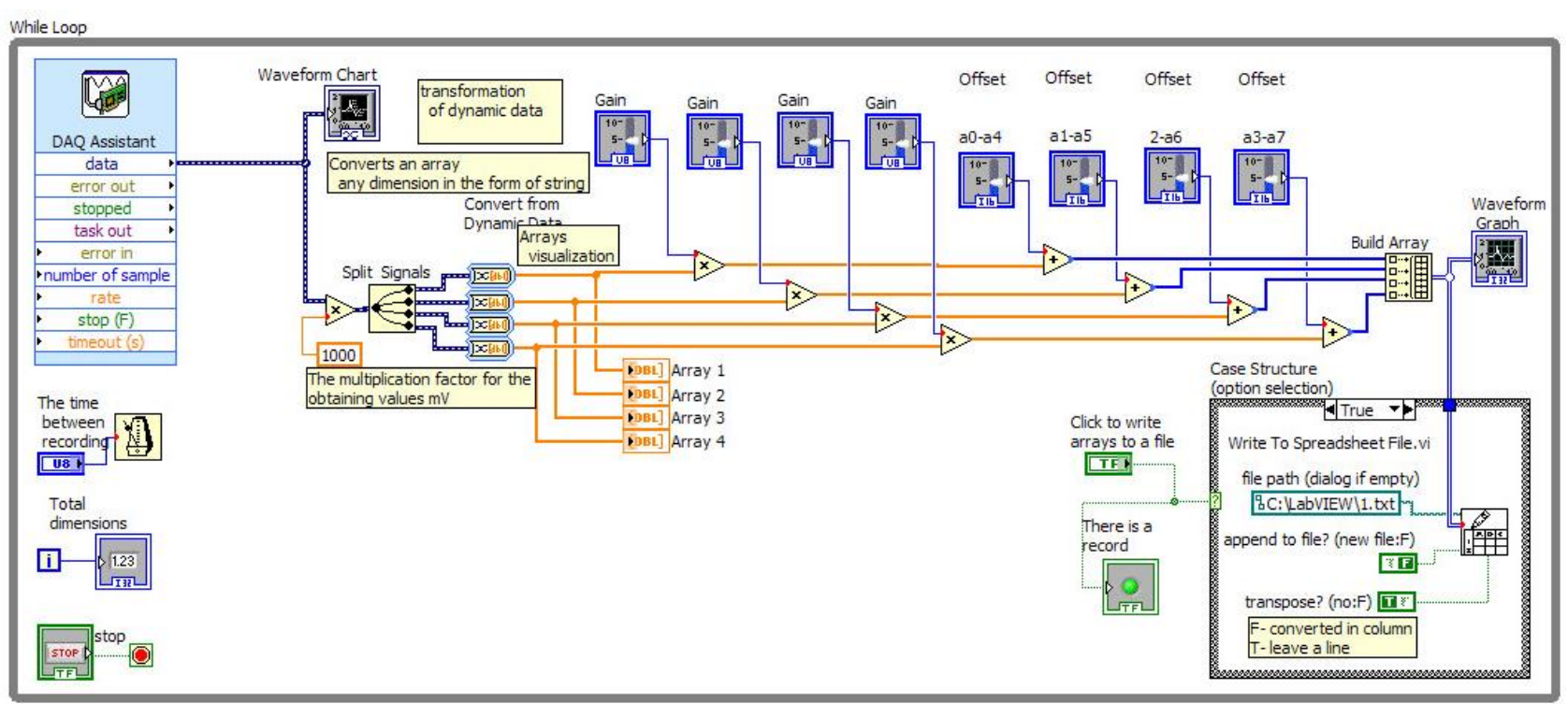

Fig. 4. Screenshot of the program written in a LabView language

Analog-to-digital converter used in experimental researches on the basic part of the governmental target No. 2014/702 «Extreme wind and wave loads on ocean engineering systems and their relation to the risk of technogenic accidents and environmental disasters» and in the research project RFBR No. 14-41-01556/14 «Fundamental research of problems of nonlinear dynamics of surface waves and their impact on ocean engineering installation in the coastal zone of the Azov - Black Sea». The essence of the works lies in the physical modeling of wave breaking processes in the coastal zone and comparing existing mathematical models with numerical results obtained in the experiment. Wave-recording gauges and membrane sensors are connected with the help of ADC. More details about the results of an experiment to investigation the shock wave loads on sloping bottom is written in [25]. Equipment connected by the ADC was calibrated. Waverecording gauges were calibrated lowering at different depths and comparing the computer recorded code with hydrostatic pressure. The correlation between the pressure and the recorded code was $\mathrm{R}^{2}=0,99$. Calibration of the sensor membranes was performed by lowering the wave-recording gauge measuring tube [22] at different depths in a bundle with a membrane sensor. The correlation between the pressure and the recorded code was $\mathrm{R}^{2}=0,945$.

\section{Conclusion}

Any limitations are inevitably introducing in the theoretical models construction of wave impacts and shock loads on the physical models of ocean engineering structures. Therefore, the problem of evaluating the reliability of the resulting model to the real process is arises, for example, by the experimental method.

In the current investigation, this problem is solved with the use of National Instruments technologies in the Ocean Technology Research Laboratory, which allowed: to increase accuracy; to simplify the implementation of different measurement methods in the certain experiment of wave characteristics determining; to reduce measuring time of the channel settings; to organize experimental data processing algorithms.

The analog-to-digital converter using in experimental researches in experimental basin allows you to record all relevant data, such as the profile of the wave, the force of wave's impact, wave characteristics and their interaction with the test physical models of offshore constructions.

Future plans are using National Instruments Technology:

- for experimental and modeling researches in the wave basin associated with the estimates of the impact of storm surges on coastal, deep water ocean engineering and hydrotechnical constructions;

- in the investigation of the problem of changes in the structure of nonlinear surface waves arising from the severe storms and the formation of impact loading at their destruction;

- for modelling and estimation of extreme wind conditions and parameters of surface waves, for the most promising areas for offshore development in the Black Sea, Caspian Sea, Sea of Okhotsk, the Barents and Kara Seas.

\section{Acknowledgments}

The reported study was funded by The Ministry of Education and Science of the Russian Federation on the basic part of the governmental target No. 2014/702. 


\section{References}

[1] Kushnir, V., Dushko, V., Kramar, V. (2013). Impact of surface gravity waves on coastal ocean engineering facilities. Eastern-European Journal of Enterprise Technologies. 6/5(66). 36-41.

[2] Kramar, V., Dushko, V., Rodkina, A., Zaiets, A. (2015). Influence of Stress-Corrosion Fractures on Potential of ShipBuilding Metals in the Sea Water. Energy Procedia. 100, 1068-1074. http://dx.doi.org/10.1016/j.proeng.2015.01.468

[3] Kramar, V., Dushko, V., Rodkina, A., Alchakov, V. (2016). Neural Network Modeling the Potential of Steels with Different Chrome Content. Proceedings Engineering of the 26th International DAAAM Symposium "Intelligent Manufacturing \& Automation" 21-24th October 2015, Zadar, Croatia, EU, Volume 26, No.1, ISSN 1726-9679, Ed. B. Katalinic, Published by DAAAM International. 0641-0647. DOI:10.2507/26th.daaam.proceedings.087

[4] Aliseichik, A.A., Galakhov, I.N., Lithonia, O.E. (1981). Plavuchie burovye platformy. Konstrukciya i prochnost' (Floating drilling platforms. The design and strength). Leningrad: Sudostroenie.

[5] Douson, T. (1986). Proektirovanie sooruzhenij morskogo shelfa (Designing of sea shelf facilites). Leningrad: Sudostroenie.

[6] Dushko, V.R. (2007). Ustojchivost morskih burovih platform na myagkih i podvizhnyh gruntah (Stability of offshore drilling platforms on soft soils and moving). PhD dissertation. Nikolaev.

[7] Lukoshkov, A.V. (1984). Tekhnika Issledovaniya Morskogo Dna (Engineering researches of the seabed). Leningrad: Sudostroenie.

[8] Pronkin, A.P., Hvorostovskij, S.S. (1999). Prognozirovanie napravlenij razvitiya razvedochnogo bureniya na shelfe (Forecasting trends in the development of exploration drilling on the continental shelf). Moscow: Nedra-biznescentr.

[9] Shostak, V.P. (2002). Ehffektivnost tekhniki osvoeniya okeana (The efficiency of ocean exploration technology). Kiev: Naukova dumka.

[10] Franchuk, V.G., Chuprun, V.P., Yaremijchuk, Ya.S., Shvachenko, I.I, Strunevich O.V. (2010). Samopodemnye burovye ustanovki: analiticheskij obzor (Self-lifting drilling rig: analytical review). Oil \& gas. 1, $28-39$.

[11] Nyrkov, A., Chernyi, S.; Zhilenkov, A. \& Sokolov, S. (2016). The use of Fuzzy Neural Structures to Increase the Reliability of Drilling Platforms. Proceedings Engineering of the 26th International DAAAM Symposium "Intelligent Manufacturing \& Automation" 21-24th October 2015, Zadar, Croatia, EU, Volume 26, No.1, ISSN 17269679, Ed. B. Katalinic, Published by DAAAM International. 0672-0677. DOI:10.2507/26th.daaam.proceedings.091

[12] Barshtejn, M.F., Zubkov, A.N., Maslov, B.E. (1974). Eksperimentalnoe izuchenie kolebanij neftepromyslovyh sooruzhenij pri neregulyarnom volnenii (Experimental study of the fluctuations of oil field facilities with irregular waves). 34. Moscow: Strojizdat.

[13] Kushnir, V.M., Dusko V.R., Fedorov S.V. (2009). Influence of the water environment on systems for shelf resourses development. Sevastopol: SevNTU Publishing.

[14] Halfin, I.Sh. (1990). Vozdejstvie voln na morskie neftegazopromyslovye sooruzheniya (The impact of waves on offshore oil and gas installations). St.Petersburg: Nedra.

[15] Srinivasan, N. (1995). Tension base TLP can support development in $4000 \mathrm{ft}$ depths. Offshore. 48-65.

[16] Demirbilek, Z.Ed. (1989). Tension Leg Platform: a state of the art review. New York: American Society of Civil Engineers.

[17] Tertyshnikova, A.S., Blagovidova, I.L., Kushnir, V.M. (2010). Parameters of the Position System for the Deep-water Drilling Platform. Vestnik SevNTU. 106. 164-167.

[18] Ivanova, O.A. (2014). Automation of leadthrough of experimental researches is in experimental tank. Vestnik SevNTU. 146. 164-167.

[19] Ivanova, O., Dushko, V., Rodkina, A. (2016). Experimental Researches Automation of Spatial Oscillations of the Floating Ocean Engineering Systems in the Wave Basin. Proceedings Engineering of the 26th International DAAAM Symposium "Intelligent Manufacturing \& Automation" 21-24th October 2015, Zadar, Croatia, EU, Volume 26, No.1, ISSN 1726-9679, Ed. B. Katalinic, Published by DAAAM International. 1059-1067. DOI:10.2507/26th.daaam.proceedings.149

[20] Kushnir, V.M., Sholar, S.A., Dushko, V.R. (2014). System for measuring impact pressure on destruction of the surface gravity waves in the near-shore. 153. 7-12.

[21] Kushnir, V.M., Dushko, V.R., Moreva, I.N., Ivanova, O.A., Fedorov, S.V. (2012). Digital system for researches of the ocean engineering systems in waves basins. Proceedings of the Odessa National Maritime University. 34. 50-65.

[22] Grekov, A.N., Grekov, N.A., Stroganov, A.S. (2007). Automated hydrodynamic wave recorder gauge. Monitoring systems of environment. 52-57.

[23] Sholar, S.A., Ivanova, O.A., Dushko V.R., Kramar V.A. (2016). The sensor for measuring the pressure of the shock wave basis of the piezoelectric. Monitoring systems of environment. 3(23). 32-37.

[24] Kushnir, V.M., Ivanova, O.A., Sholar, S.A. (2015). Transformation, destruction and shots of marine waves on sloping seabed in off-shore zone. Saarbrücken: LAP LAMBERT Academic Publishing.

[25] Kushnir, V.M., Sholar, S.A., Dushko, V.R. (2016). Experimental research of dynamic loads formed upon breaking of a gravitational wave on a sloping bottom. Instruments and Experimental Techniques. 59. 451-457. 